\title{
THE INFLUENCE OF CHITOSAN TOWARDS ANTIBACTERIAL PROPERTIES IN NATURAL LEATHER
}

\author{
Mustafidah UDKHIYATI ${ }^{1 *}$, Nur Mutia ROSIATI ${ }^{1}$, Fitrilia SILVIANTI ${ }^{2}$ \\ ${ }^{1}$ Department of Leather Processing Technology, Politeknik ATK Yogyakarta, Sewon, Bantul, 55188, Yogyakarta, Indonesia, \\ ukyfida@gmail.com \\ ${ }^{2}$ Department of Rubber and Plastic Processing Technology, Politeknik ATK Yogyakarta, Sewon, Bantul, 55188, Yogyakarta, \\ Indonesia
}

Received: 10.02 .2020

Accepted: 03.12.2020

https://doi.org/10.24264/Ifj.20.4.8

THE INFLUENCE OF CHITOSAN TOWARDS ANTIBACTERIAL PROPERTIES IN NATURAL LEATHER

ABSTRACT. The abundant hydroxyl groups $(-\mathrm{OH})$ of vegetable tanned leather enhances the bacterial growth possibility. In this work, antibacterial vegetable tanned leather was developed taking advantage of chitosan antibacterial activity. Different chitosan utilization method was conducted, namely drum impregnation and spraying. Antibacterial testing was carried out using agar diffusion method to identify the effect of chitosan against Gram-positive bacteria (Staphylococcus aureus). The results showed that the use of $1 \%(\mathrm{w} / \mathrm{v}$ ) chitosan by spraying method tends to be more effective in improving the antibacterial properties of vegetable tanned leather. While, the leather sample of drum impregnation at initial $\mathrm{pH} 4$ has the lowest antibacterial activity among others. The results of FTIR analysis showed that there was no significant difference between control and chitosan modified tanned leather, confirming the similar functional groups between it.

KEY WORDS: leather, antibacterial, chitosan

\section{INFLUENTA CHITOSANULUI ASUPRA PROPRIETĂTIILOR ANTIBACTERIENE ALE PIELII NATURALE}

REZUMAT. Grupările hidroxilice $(-\mathrm{OH})$ care se găsesc din abundență în pielea tăbăcită vegetal favorizează creșterea bacteriană. În această lucrare s-a tratat pielea tăbăcită vegetal cu chitosan pentru a-i oferi proprietăți antibacteriene. Chitosanul a fost aplicat prin impregnare în tambur și prin pulverizare. Testarea antibacteriană a fost efectuată folosind metoda de difuzie în agar pentru a identifica efectul chitosanului asupra bacteriilor Gram-pozitive (Staphylococcus aureus). Rezultatele au arătat că utilizarea a $1 \%$ chitosan $(\mathrm{m} / \mathrm{v})$ prin metoda pulverizării tinde să fie mai eficientă în îmbunătățirea proprietăților antibacteriene ale pielii tăbăcite vegetal. Proba de piele impregnată cu chitosan în tambur la pH-ul inițial 4 are cea mai mică activitate antibacteriană, printre altele. Rezultatele analizei FTIR au arătat că nu a existat nicio diferență semnificativă între proba martor și pielea tăbăcită tratată cu chitosan, confirmând grupările funcționale similare ale acestora.

CUVINTE CHEIE: piele, antibacterian, chitosan

\section{L'INFLUENCE DU CHITOSANE SUR LES PROPRIÉTÉS ANTIBACTÉRIENNES DU CUIR NATUREL}

RÉSUMÉ. Les groupes hydroxyle $(-\mathrm{OH})$ que l'on trouve en abondance dans le cuir à tannage végétal favorisent la croissance bactérienne. Dans cet article, la peau tannée végétale a été traitée avec du chitosane pour lui conférer des propriétés antibactériennes. Le chitosane a été appliqué par imprégnation dans le tambour et par pulvérisation. Des tests antibactériens ont été réalisés en utilisant la méthode de diffusion sur gélose pour identifier l'effet du chitosane sur les bactéries Gram-positives (Staphylococcus aureus). Les résultats ont montré que l'utilisation de $1 \%$ de chitosane $(\mathrm{m} / \mathrm{v})$ par la méthode de pulvérisation tendent à être plus efficace pour améliorer les propriétés antibactériennes du cuir à tannage végétal. L'échantillon de cuir imprégné de chitosane dans le tambour au pH initial de 4 a, entre autres, l'activité antibactérienne la plus faible. Les résultats de l'analyse FTIR ont montré qu'il n'y avait pas de différence significative entre l'échantillon témoin et le cuir traité au chitosane, confirmant leurs groupes fonctionnels similaires.

MOTS CLÉS : cuir, antibactérien, chitosane

\footnotetext{
* Correspondence to: Mustafidah UDKHIYATI, Department of Leather Processing Technology, Politeknik ATK Yogyakarta, Sewon, Bantul, 55188, Yogyakarta, Indonesia, ukyfida@gmail.com
} 


\section{INTRODUCTION}

The challenges of the global industry are improving dynamically following various pressures including globalization of world trade, standardization, and also government regulations. If in the past the operating system focused on low costs, in the present era it is expected that the operating system is also considerate to environmental problems. Especially in leather section, the establishment of the ASEAN Free Trade Area (AFTA) since 2015, increasing competition in the global leather market [1]. Therefore, alternative tanning processes that are more environmentally friendly are needed, especially considering the leather tanning industry which has been known as a waste contributor industry. The use of chrome as a main tanning agent is known to be a health and environmental risk. Alternative to environmentally friendly tanning processes can be considered with the utilization of natural tanning agent. However, the durability problem is still the limitation of natural leather.

The vegetable tanning agent (tannin) contains abundant hydroxyl groups $(-\mathrm{OH})$, thus vegetable tanned leather has the potential to be a good bacterial growth medium [2]. Coating process is one of the efforts that can be done to increase the leather antibacterial properties [3]. Various antibacterial agents have been developed to produce antibacterial properties in a material. Some organic materials that have been widely developed as antibacterial agents are Eucalyptus, Lavender [4], Origanum minutiflorum [5], and chitosan [3,6]. Chitosan is an organic material that has high potential to be developed as an antibacterial agent. Chitosan ( $\alpha$ - (1-4) -2-amino2 -deoxy- $\beta$-D-glucan) is a chitin derivative that is abundant, non-toxic, and easily degraded in nature [7]. The antibacterial ability of chitosan to microorganisms such as bacteria, molds and fungi has become an interesting study in various fields. Some research to confer antimicrobial capacity in the leather industry have been reported as a result of the use of a methacrylic acid-acrylamide-chitosan copolymer [8], development of chitosan-based antimicrobial leather coatings in footwear material made from wet blue (chrome tanning) [3], and initial study of chitosan utilization in natural leather [9]. However, those previous studies have not observed yet the effect of different concentration and the utilization method of chitosan towards the antibacterial properties of natural leather. It is expected that through the experimental application with several method variations, the optimal conditions for the use of chitosan as an antibacterial agent on natural skin is obtained.

\section{EXPERIMENTAL}

\section{Materials and Methods}

\section{Materials}

Chitosan (Pharmaceutical Grade) corresponding to flakes with size $149 \mu \mathrm{m}$, deacetylation degree $94 \%$, and dynamic viscosity of $100 \mathrm{mPa}$.s purchased from CV. ChiMultiguna was used. Chitosan solutions were prepared by mixing the desired amount of chitosan in formic acid aqueous solutions ( $2 \%, v / v)$, with stirring overnight (200 rpm at 50ㅇ) [3]. Formic acid was chosen since it is the most referred in the literature and due to its use in the tanning industry (Tannin and Dye Fixation Stage).

\section{Instrumentations}

Characterization using Fourier Transform InfraRed (FTIR) (Perkin-Elmer) was carried out to determine functional group of leather sample. Leather Samples Coating Processes

Sheep pickled skins were processed by vegetable tanning method. Leather samples were collected after fatliquoring fixation stage (Figure 1). Different approaches for coating were tested at a pilot scale, they were:

a) Impregnation using drum: impregnations were carried out at different initial $\mathrm{pH}$ (3 and 4), using 1.0\% (chitosan/leather 
ratio, $\mathrm{w} / \mathrm{w})$, prepared in $2 \%(\mathrm{v} / \mathrm{v})$ formic acid solutions. The initial $\mathrm{pH}$ variation of impregnation was conducted to identify the effect of $\mathrm{pH}$ on the antibacterial activity of chitosan. The absorption of chitosan to the leather was analyzed by comparing the initial concentration of chitosan with the concentration of chitosan after the process is finished (residual).

b) Spraying: chitosan solution $(1 \%, w / v$, formic acid) was applied as a finishing step using the spray-gun placed at a distance of $14 \mathrm{~cm}$ from the leather sample. For control purposes, leather samples without chitosan coating were prepared.

\section{SHEEP PICKLED SKIN \\ VEGETABLE TANNING \\ FATLIQUORING \\ CHITOSAN COATING (Impregnation in Drum)}

DRYING

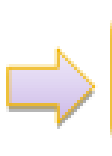

CHITOSAN COATING (Spraying)

Figure 1. Procedure Scheme in Experiment

Antibacterial Activity Assays

Antibacterial testing was carried out using agar diffusion method to identify the effect of chitosan against Gram-positive bacteria (Staphylococcus aureus). Briefly, the bacteria inoculum was prepared by aseptically transferring 4 isolated colonies to nutrient broth, which was then incubated during $24 \mathrm{~h}$ at $37 \pm 1$ 으. The inoculum was diluted to $0.5 \mathrm{McF}$ arland turbidity standard (corresponding to a concentration of 1.5-3.0×108 CFU/mL). Antibacterial activity test was conducted by placing the leather sample $(2 \mathrm{~cm} \times 2 \mathrm{~cm})$ on a petri dish containing $0.5 \mathrm{~mL}$ of bacterial inoculant in $20 \mathrm{~mL}$ nutrient agar. The Petri dish was then incubated for 24 hours at $37 \pm 1$ 으. Bacterial growth inhibition was observed by measuring the clear area at the edge of the leather sample in Petri dish.

\section{RESULTS AND DISCUSSIONS}

\section{FTIR Analysis}

The results of the infrared absorption of leather control were shown in Figure 2. The stretching vibration of $\mathrm{O}-\mathrm{H}$ and it of $\mathrm{N}-\mathrm{H}$ from collagen were proven by the appearance of broad absorption bands due to the formation of hydrogen bonds in the region $3402 \mathrm{~cm}^{-}$ 1. The band at $2924 \mathrm{~cm}^{-1}$ was resulted from the stretching vibration of the $\mathrm{C}-\mathrm{H}$ bond [10]. Amide I absorption was observed at wave number of $1651 \mathrm{~cm}^{-1}$ which was the stretching vibration of the collagen carbonyl group. This absorption band was overlapping with absorbance of $-\mathrm{OH}$ bending vibration. Amide II characteristic absorption shown at $1543 \mathrm{~cm}^{-1}$ due to $\mathrm{C}-\mathrm{N}$ stretching vibration overlapping with 
$\mathrm{N}-\mathrm{H}$ bending vibration [11-14]. The stretching vibration of C-N was also observed at $1450 \mathrm{~cm}^{-1}$. The absorption band at $1234 \mathrm{~cm}^{-1}$ was attributed to the presence of amide III of leather [12].
Meanwhile, the absorption of the methylene group appeared at the $1342 \mathrm{~cm}^{-1}$, and the stretching vibrations of $\mathrm{C}-\mathrm{O}-\mathrm{C}$ were seen in the region of 1034-1165 $\mathrm{cm}^{-1}[10]$.

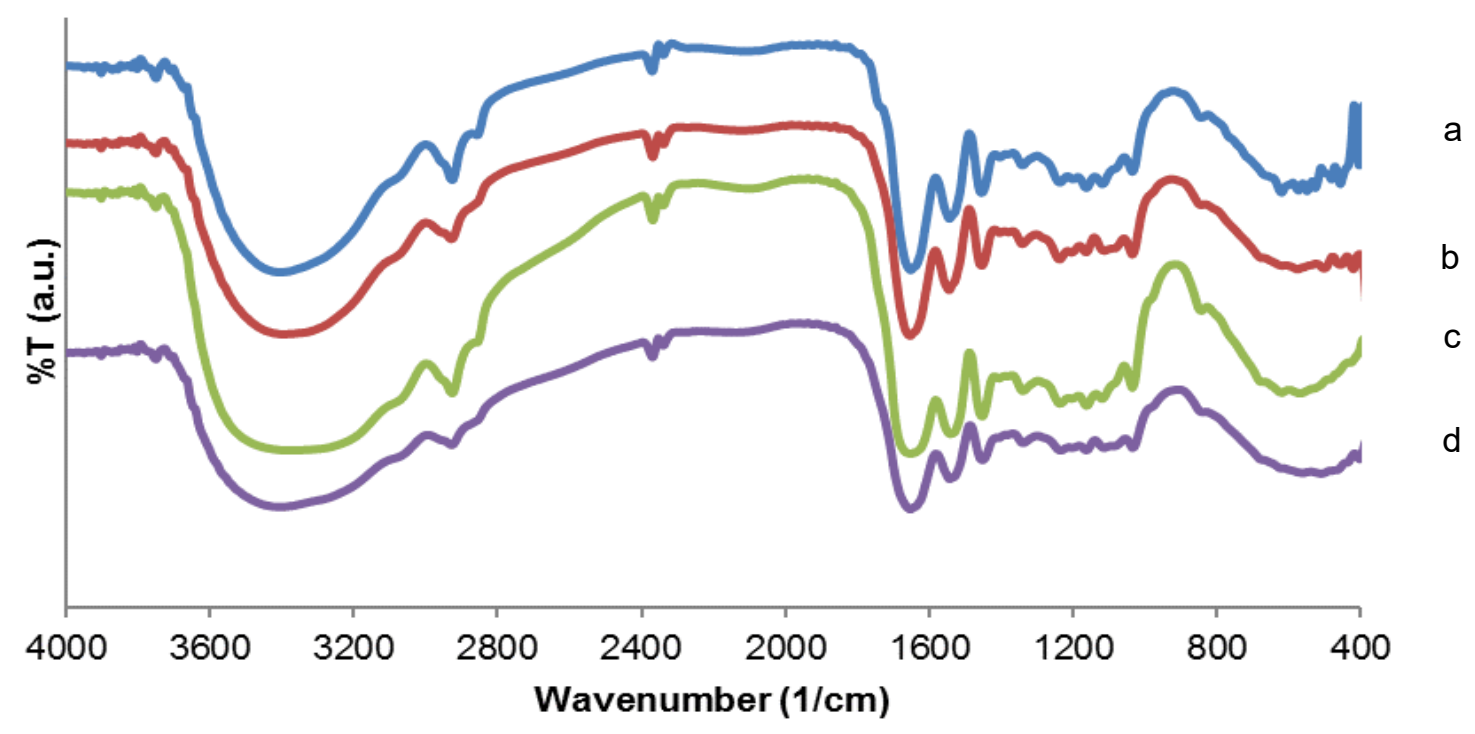

Figure 2. FTIR spectra. Control (a), impregnation in drum at initial pH 3 (b), pH 4 (c), spraying (d)

FTIR spectra showed no significant alteration between the infrared absorption of control leather with chitosan modified leather. This happened because the functional groups in chitosan were the same as the functional groups in the control leather, containing methylene, amine and carbonyl groups. The broad absorption band in the region of $3380-3400 \mathrm{~cm}^{-1}$ and 555 $617 \mathrm{~cm}^{-1}$ showed the existence of $\mathrm{O}-\mathrm{H}$ and $\mathrm{N}-\mathrm{H}$ stretching vibrations from collagen and chitosan $[10,14]$. The absorption band was observed to be broader after being modified with chitosan. This phenomenon proved that more hydrogen bonds were formed due to chitosan modification in the leather. The presence of a methylene group was characterized by the visible absorption at 2924$2932 \mathrm{~cm}^{-1}$ as asymmetrical stretching vibrations and $1335-1342 \mathrm{~cm}^{-1}$ as bending vibrations $[10,15,16]$. Based on Figure 5, there was no wavenumber shift of amide groups I, II, and III. It showed that there were no alteration bonds due to the modification chitosan in the leather.

\section{Effect of Initial pH and Different Type of Coating} on Antibacterial Activity of Chitosan

By visually observing the inhibition zones displayed around the samples coated, the spraying sample treatment showed the largest inhibition zone among the treatments (Figure $3)$. The difference is increasingly visible in the measurement results of bacterial inhibition area. The result showed that though was not statistically significant, the highest value of bacterial inhibition area was shown in the spraying sample group with a value about $582.67 \mathrm{~mm}^{2}$ (Table 1). Meanwhile, the tendency of antibacterial activity of the drum method at $\mathrm{pH} 3$ and 4 were less effective as the lower value of inhibition area than the control. Based on the results obtained there is a tendency that the use of chitosan as an antibacterial on vegetable tanned leather was more effective in the spraying method compared to the impregnation method in the drum. 


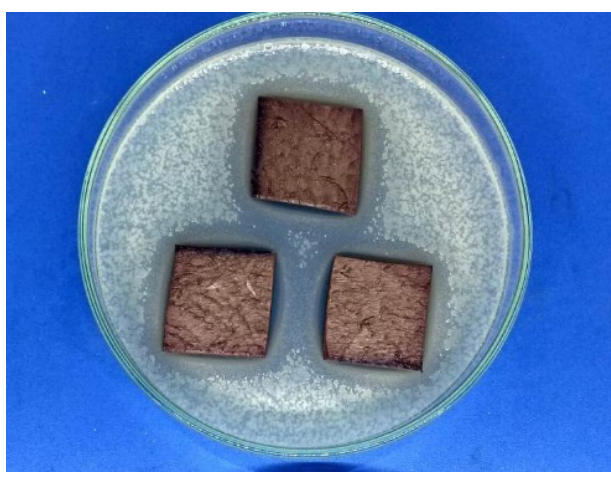

(a)

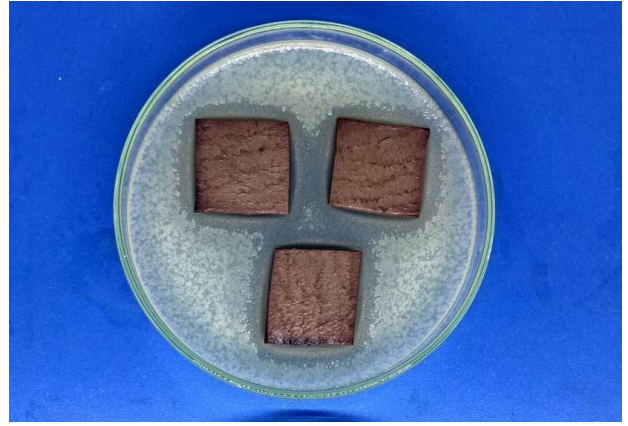

(c)

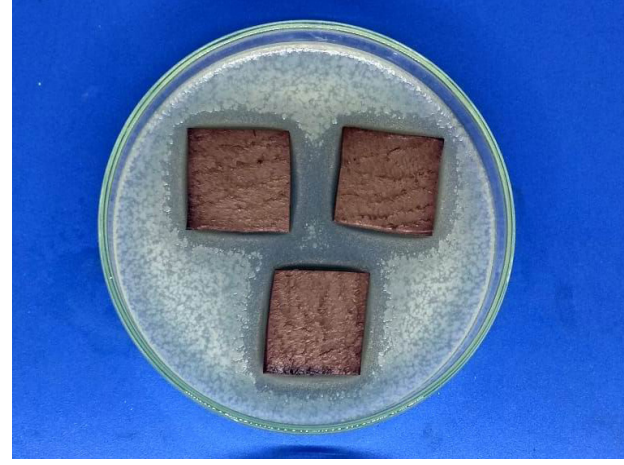

(b)

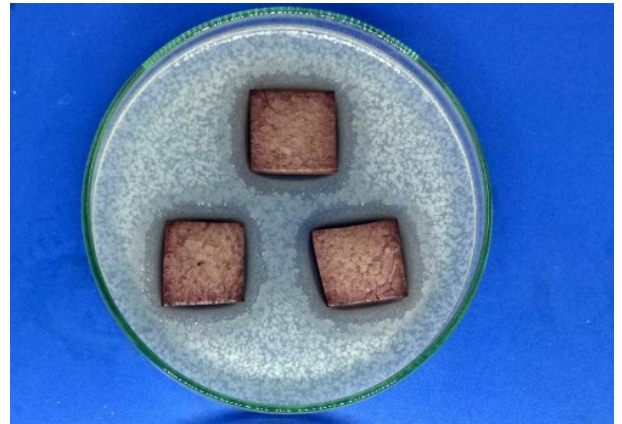

(d)

Figure 3. Measurement of antibacterial activity using agar diffusion method: a) control; b) spraying; c) impregnation in drum at initial $\mathrm{pH} 3$; d) $\mathrm{pH} 4$

Table 1: Bacterial inhibition area

\begin{tabular}{|c|c|c|c|c|c|}
\hline \multirow[b]{2}{*}{ No } & \multirow[b]{2}{*}{ Leather Samples } & \multicolumn{3}{|c|}{ Inhibition Area $\left(\mathrm{mm}^{2}\right)$} & \multirow{2}{*}{ Average } \\
\hline & & 1 & 2 & 3 & \\
\hline 1 & Control & 500 & 500 & 561 & $520,33^{b}$ \\
\hline 2 & Spraying & 500 & 624 & 624 & $582,67^{b}$ \\
\hline 3 & $\mathrm{pH} 3(1 \%)$ & 500 & 500 & 500 & $500,00^{b}$ \\
\hline 4 & $\mathrm{pH} 4(1 \%)$ & 384 & 276 & 276 & $312^{\mathrm{a}}$ \\
\hline
\end{tabular}

This phenomenon can be explained that basically in addition to chitosan, antibacterial activity was also influenced by the interaction of vegetable tanning agent (tannin) against the leather. Vegetable tanning agent that used in this study was mimosa, which was the type of vegetable condensed tannin. This type of vegetable tanning agent consists of flavonoid structures, some of them were in the form of gallocatechin and epigallocatechin [17]. Flavonoids have specific antibacterial mechanism depending on the type of flavonoid. For example, epigallocatechin has antibacterial mechanism by inhibiting the function of cytoplasmic membrane [18].

In the case of spraying leather, the surface of vegetable tanned leather is rich of polyphenol groups thus had high possibility to react with chitosan in several possible bond types. Including covalent bonding (Figure 4) as well as the hydrogen bond between - $\mathrm{OH}$ of the polyphenol group and amine of chitosan [19]. The interactions formed by chitosan and polyphenols on the surface of the vegetable tanned leather affect the enhancement of the antibacterial properties of leather. Chitosan antibacterial mechanism can be affected by the interaction between the positively charged chitosan and the negatively charged microbial cell wall leads to the leakage of the intracellular constituents. The binding of chitosan with DNA and the inhibition of mRNA synthesis occurs via the penetration of chitosan into the nuclei of the microorganisms and interfering with the synthesis of mRNA and proteins [20]. 


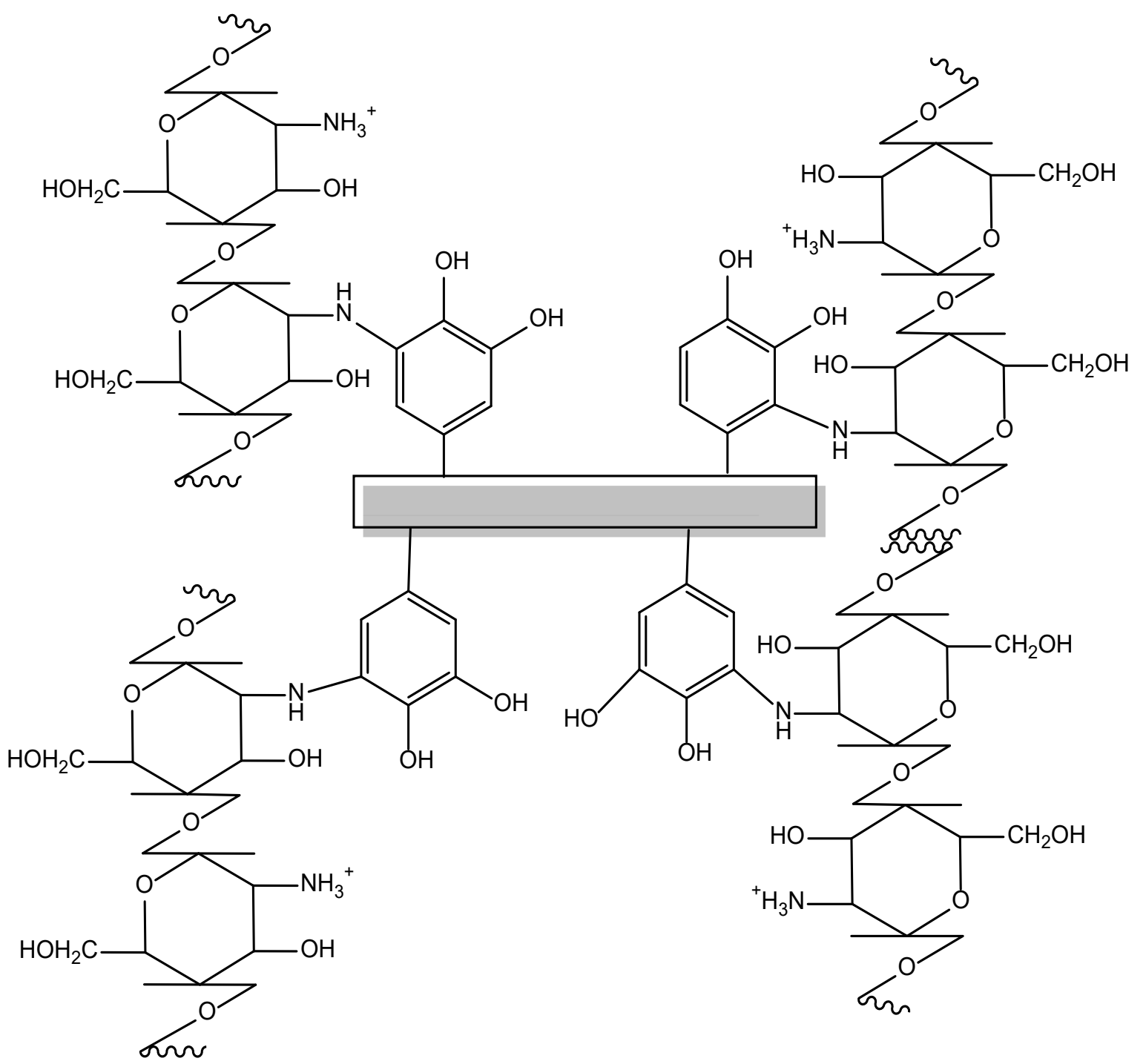

Figure 4. Interaction model of chitosan bonding on the natural leather surface

Meanwhile, the different possible interaction of chitosan in the drum method leather affect the antibacterial properties of leather. The possible interactions are hydrogen bonding between chitosan and collagen (Figure 5) and covalent bonding between chitosan and polyphenol on the leather surface as occurred in the spraying leather (Figure 4). The presence of amine groups in chitosan initiates the formation of strong hydrogen bonds between phenolic groups and amine groups in chitosan [19]. The direct interaction of chitosan and collagen allows the reduction of interaction between tannins and leather, thereby exerting an influence on the antibacterial effect produced by tannin. This phenomenon might explain the low antibacterial properties of the drum impregnation method group. Antibacterial properties of leather group with chitosan impregnation treatment at initial pH 4 showed the lowest significantly among the other three groups. This is thought to be influenced also by the differences in levels of chitosan that is absorbed into the leather. 


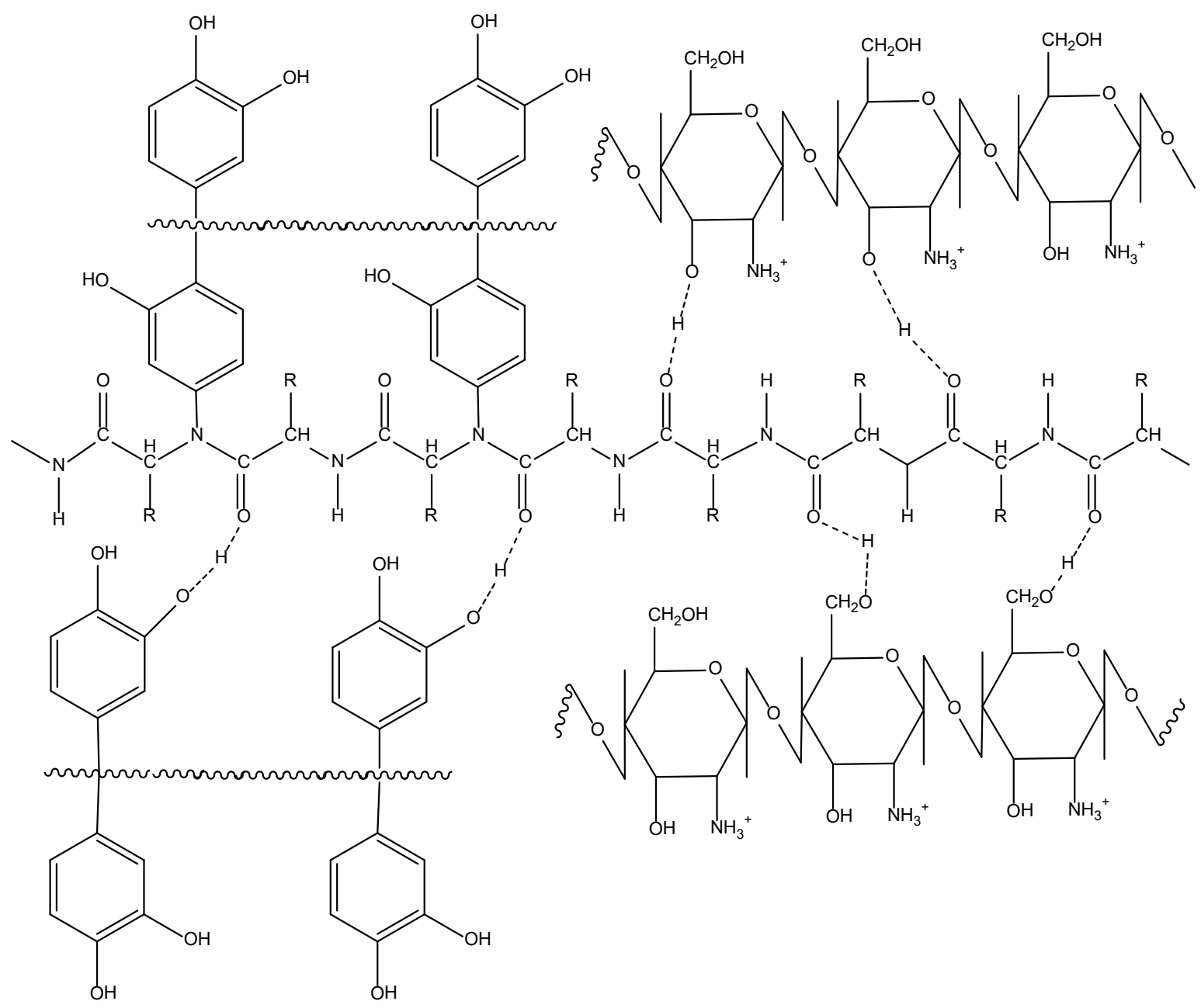

Figure 5. Interaction model of the hydrogen bonding between chitosan and collagen

Based on the results obtained, chitosan residual amount in waste of the drum method group with initial $\mathrm{pH} 4$ higher than the $\mathrm{pH} 3$ (Table 2). It showed that the amount of chitosan absorbed into the leather on $\mathrm{pH} 3$ higher than $\mathrm{pH} 4$ group. The higher amount of chitosan absorbed in the leather has been clearly proven to increase the antibacterial properties of the leather. The antibacterial ability of chitosan is strongly influenced by $\mathrm{pH}$. This is related to the level of solubility of chitosan in an acidic atmosphere, and the change in the chitosan molecule to polycationic as the $\mathrm{pH}$ decreases below pKa (6.3-6.5) [21, 22]. The polycationic structure of chitosan is a prerequisite for antibacterial activity. As environmental $\mathrm{pH}$ is below the pKa of chitosan and its derivatives, electrostatic interaction between the polycationic structure and the predominantly anionic components of the microorganisms' surface [22]. Although according to previous studies it was mentioned that the antibacterial properties of chitosan decreased below pKa (6.36.5), but in this experiment at $\mathrm{pH} 4$ a decrease in the antibacterial ability of chitosan has begun. 
Table 2: Chitosan residual determination

\begin{tabular}{ccccc}
\hline \multirow{2}{*}{ No } & \multirow{2}{*}{ Sample } & \multicolumn{3}{c}{ Weight of chitosan residual deposition in waste } \\
& & 1 & (gram) & Average \\
\hline 1 & $\mathrm{pH} \mathrm{3(1 \% )}$ & 0.035 & 0.033 & 0.034 \\
2 & $\mathrm{pH} \mathrm{4(1 \% )}$ & 0.072 & 0.037 & 0.055 \\
\hline
\end{tabular}

\section{CONCLUSIONS}

The evaluation of antibacterial activity of chitosan against Gram-positive bacteria (Staphylococcus aureus) based on different method confirmed that the impregnation in drum method sample have lower antibacterial activity than spraying. There is a tendency that the use of chitosan as an antibacterial on vegetable tanned leather was more effective in the spraying method compared to the impregnation method in the drum, showed by the highest value of bacterial inhibition area about $582.67 \mathrm{~mm}^{2}$. The leather sample of drum impregnation at initial $\mathrm{pH} 4$ has the lowest antibacterial activity among others. Meanwhile, based on FTIR spectra there was no alteration absorption bands due to the modification chitosan in the leather.

\section{Acknowledgements}

This work was funded by Politeknik ATK Yogyakarta through research grant of Riset Pembinaan, contract number 178/SK/BPSDMI/ ATK/XII/2019.

\section{REFERENCES}

1. Purba, F., Green Productivity of Indonesia Leather Industry (Case Study in Bogor and Magetan District) (Produktivitas Hijau Industri Kulit Samak Indonesia (Studi Kasus di Bogor dan Magetan)), Bogor: Sekolah Pascasarjana, Institut Pertanian Bogor, 2018.

2. Orlita, A., Microbial biodeterioration of leather and its control: a review, Int Biodeterior.
Biodegrad, 2004, 53, 157-163, https://doi. org/10.1016/S0964-8305(03)00089-1.

3. Fernandes, I.P., Amaral, J.S., Pinto, V., Ferreira, M.J., Barreiro, M.F., Development of chitosan-based antimicrobial leather coatings, Carbohydr Polym, 2013, 98, 1229-1235, https://doi.org/10.1016/j. carbpol.2013.07.030.

4. Sirvaityte, J., Siugzdaite, J., Valeika, V., Application of Commercial Essential Oils of Eucalyptus and Lavender as Natural Preservative for Leather Tanning Industry, Rev Chim, 2011, 10, https://doi.org/10.3176/ proc.2012.3.12.

5. Bayramoglu, E.E.E., Natural and Environmentfriendly New Bactericide for Leather Industry: Essential Oil of Origanum minutiflorum, J Biol Sci, 2005, 5, 455-457, https://doi. org/10.3923/jbs.2005.455.457.

6. Zhang, Z., Chen, L., Ji, J., Huang, Y., Chen, D., Antibacterial Properties of Cotton Fabrics Treated with Chitosan, Text Res J, 2003, 73, 1103-1106, https://doi. org/10.1177/004051750307301213.

7. Panos, I., Acosta, N., Heras, A., New Drug Delivery Systems Based on Chitosan, Curr Drug Discov Technol, 2008, 5, 333-341, https://doi. org/10.2174/157016308786733528.

8. Lv, S.H., Yan, X.L., Gao, R.J., Preparation and Properties of Copolymer of Methacrylic Acid and Acrylamide onto Degraded Chitosan Initiated by HRP/H2O2/ACAC, Appl Mech Mater, 2011, 80-81, 396-399, https://doi. 
org/10.4028/www.scientific.net/AMM.8081.396.

9. Udkhiyati, M., Silvianti, F., The Utilization of Chitosan as Natural Antibacterial for Vegetable Tanned Leather, Mater Sci Forum, 2019, 948, 212-216, https://doi.org/10.4028/ www.scientific.net/MSF.948.212.

10. Corazzari, I., Nisticò, R., Turci, F., Faga, M.G., Franzoso, F., Tabasso, S., Magnacca, G., Advanced physico-chemical characterization of chitosan by means of TGA coupled on-line with FTIR and GCMS: Thermal degradation and water adsorption capacity, Polym DegradStab, 2015, 112, 1-9, https://doi.org/10.1016/j. polymdegradstab.2014.12.006.

11. Bekale, L., Agudelo, D., Tajmir-Riahi, H.A., Effect of polymer molecular weight on chitosan-protein interaction, Colloids Surf $B$ Biointerfaces, 2015, 125, 309-317, https:// doi.org/10.1016/j.colsurfb.2014.11.037.

12. Lu, Z., Xiao, J., Wang, Y., Meng, M., In situ synthesis of silver nanoparticles uniformly distributed on polydopamine-coated silk fibers for antibacterial application, J Colloid Interface Sci, 2015, 452, 8-14, https://doi. org/10.1016/j.jcis.2015.04.015.

13. Ramalingam, S., Sreeram, K.J., Rao, J.R., Nair, B.U., Organic Nano-colourants: A self-fixed, optothermal resistive silica supported dyes for sustainable dyeing of leather, ACS Sustain Chem Eng, 2016, 4, 5, 2706-2714, https:// doi.org/10.1021/acssuschemeng.6b00218.

14. Djobo, Y.J.N., Elimbi, A., Dika Manga, J., Djon Li Ndjock, I.B., Partial replacement of volcanic ash by bauxite and calcined oyster shell in the synthesis of volcanic ash-based geopolymers, Constr Build Mater, 2016, 113, 673-681, https://doi.org/10.1016/j. conbuildmat.2016.03.104.

15. Pan, H., Li, G.-L., Liu, R.-Q., Wang, S.-X., Wang, X.-D., Preparation, characterization and application of dispersible and spherical Nano-SiO2@Copolymer nanocomposite in leather tanning, Appl Surf Sci, 2017, 426, 376-385, https://doi.org/10.1016/j. apsusc.2017.07.106.

16. Nuryono, N., Rosiati, N.M., Rettob, A.L., Suyanta, S., Arryanto, Y., Coating of 2-Aminobenzimidiazole and 1-(o-Tolyl) biguanide Functionalized Silicas on Iron Sand Magnetic Material for Sorption of [AuCl4]-, Indones J Chem, 2019, 19, 395, https://doi. org/10.22146/ijc.34653.

17. Covington, A.D., Tanning chemistry: the science of leather, Cambridge, UK: Royal Society of Chemistry, 2009.

18. Cushnie, T.P.T., Lamb, A.J., Antimicrobial activity of flavonoids, Int J Antimicrob Agents, 2005, 26, 343-356, https://doi. org/10.1016/j.ijantimicag.2005.09.002.

19. Girardi, L.G.J., Morsch, M., Cechinel-Filho, V., Meyre-Silva, C., Rodrigues, C.A., Isolation of flavonoids from Aleurites moluccana using chitosan modified with benzaldehyde ( $\mathrm{CH}-\mathrm{Bz})$ as chromatographic support, Die Pharmazie, 2003, 58, 9, available at: https:// www.ingentaconnect.com/content/govi/ pharmaz/2003/00000058/00000009/ art00006\# [Accessed October 9, 2019].

20. Banerjee, M., Mallick, S., Paul, A., Chattopadhyay, A., Ghosh, S.S., Heightened Reactive Oxygen Species Generation in the Antimicrobial Activity of a Three Component lodinated Chitosan-Silver Nanoparticle Composite, Langmuir, 2010, 26, 8, 59015908, https://doi.org/10.1021/la9038528.

21. Lim, S.-H., Hudson, S.M., Application of a fiber-reactive chitosan derivative to cotton fabric as an antimicrobial textile finish, Carbohydr Polym, 2004, 56, 227-234, https:// doi.org/10.1016/j.carbpol.2004.02.005. 
22. Kong, M., Chen, X.G., Xing, K., Park, H.J., Antimicrobial properties of chitosan and mode of action: A state of the art review, Int J Food Microbiol, 2010, 144, 51-63, https:// doi.org/10.1016/j.ijfoodmicro.2010.09.012.
(C) 2020 by the author(s). Published by INCDTPICPI, Bucharest, RO. This is an open access article distributed under the terms and conditions of the Creative Commons Attribution license (http:// creativecommons.org/licenses/by/4.0/). 